\title{
THE ROLE OF QUALITY EDUCATION IN THE MECHANISM OF TRANSPARENCY STATE AUTHORITIES
}

\author{
Zhaxybay Suingariyev ${ }^{1 *}$, Duissekul Kunanbayeva ${ }^{1}$, Aizat Kunanbayeva ${ }^{2}$, and Mikhail \\ Molchanov $^{3}$ \\ ${ }^{1}$ Al-Farabi Kazakh National University, Department of Management, al-Farabi Ave. 71, 050040 \\ Almaty, Republic of Kazakhstan \\ ${ }^{2}$ L.N.Gumilev Eurasian National University, Department of social pedagogy and self-knowledge, \\ Satbaev st. 2, 010000 Nur Sultan, Republic of Kazakhstan \\ ${ }^{3}$ University of Victoria, Government of British Columbia, Policy Analyst, Canada
}

\begin{abstract}
In modern society, the importance of quality education is steadily increasing, and the spiritual, cultural and moral potential of society is associated with its development. Based on a study of the civic education model, we will present elements related to the country's commitment to open government at the international level and propose strategies for implementing specific policies that support these commitments regarding education and global citizenship. Therefore, our goal is to provide the scientific community with practical tools for quality education in the mechanism of openness of state bodies based on Al-Farabi's research.

The need of society and the state for the innovative development of the economy in a rapidly developing world is continuously associated with the improvement of universities in the formation of vocational training for graduates - future specialists. The country needs such personnel who are ready to create and introduce innovations in the field of open government, with the possibility of control by society, as well as the dynamic cooperation in active way of participation of citizens themselves in management and to monitor government initiatives and their legitimacy. Continuous improvement of the quality of education should be the goal not only of the country's leadership, but also of each citizen individually and of society as a whole.
\end{abstract}

\section{Introduction}

Social transformations and innovations, various reforms affecting the modernization of mass consciousness, and which have occurred in recent years in Kazakhstan and a number of other countries have sharpened interest in understanding the nature of the state, its institutions and management methods. It is designed to promote the unification of people, the adoption in the mass consciousness of the social idea of the priority of state and national interests. The relevance of these issues is of particular significance in conditions when the system of the state's execution of its capacities has not yet been settled, the connection scheme between society and government organizations.

*Corresponding author: ertis_economika@mail.ru 
The resignation of the first president of Kazakhstan, Nursultan Nazarbayev, and the process of "transit" of power to the current president of the republic, Kasym-Zhomart Tokaev, launched the process of new reforms in the country, including in the field of education and public administration. [1]

In a speech by the President of the country, Kassym-Zhomart Tokayev, at an expanded meeting of the Government of the Republic of Kazakhstan on January 24, 2020, the President emphasizes that the goals and objectives set by the First President of the Republic of Kazakhstan - Elbasy before the country remain unchanged. The Kazakhstan-2050 Strategy, the Strategic Plan for the Development of the Country until 2025, 100 Steps of the Nation Plan. But at the same time, modernization requires a "reset" of approaches to achieve these strategic goals.

For example, a number of initiatives voiced by the President, such as the creation of the National Council of Public Confidence, the implementation of the concept of a "hearing state" (open and transparent), the formation of the Presidential youth personnel reserve. One the one hand, its show us, the president's deep understanding of the domestic political situation and the demands of the population and, on the other hand, testify to the growing role of the individual for the state, the importance and recognition of his merits.

The topic of openness and transparency of power has been touched upon in many Kazakhstan and foreign sources. In the context of the study, the focus is on the so-called "information transparency" or "transparency", which implies not only the availability of information about the activities of public authorities, but also the possibility of control by society, as well as the participation of citizens themselves in governance. Of particular importance at the moment is the implementation of the direction of ensuring an effective information policy, in which representatives of the Kazakhstani political elite, the power apparatus, parties and various social movements are directly interested.

\section{Literature review}

In endogenous growth theory, education promotes innovation, knowledge of new technologies and products, thereby contributing to economic growth. The existing literature has broadly discussed the relationship between education and economic growth. Schultz [2] mentioned that the educational investment and other aspects could also accelerate the economic growth in the Declaration of Human Capital Investment in 1960. Denison [3], the father of growth accounting, estimated the contribution rate of education to the national annual income growth $(2.93 \%)$ by residues analysis and found that education contributed $35 \%$ in United States, which pointed out that education makes great contributions to economic growth. William and Rebelo [4] found that there is a positive correlation between public education investment and economic growth. A group of scientists headed by Collins et al. [5] estimated the contribution of per capita education to the per capita growth among seven Asian countries, finding that the contribution of education investment to economic growth occupied 9.7\% in South Korea from 1984 to 1994. It can be concluded that education is an important factor influencing economic growth. Sylwester [6] also indicated that although education spending has a negative effect on economic growth in the short term, it plays a positive role in the long run.

The authors (Petychakis et al., 05, 2014) [7] do not focus on one aspect of their assessment. Rather, they conduct a comprehensive analysis of initiatives in the field of open public data in the European Union, with particular emphasis on functions, data semantics and functions. They collect and classify a number of open data sources for each member state of 
the European Union, and also evaluate their characteristics and the services provided. The authors identify differences in content, licenses, multilingualism, data availability, data provision, and data format. Finally, the authors point out that while the quality of open government infrastructure is improving, there are still large differences between national open data portals. The authors also identify two important issues that have not yet been resolved, namely, multilingualism and open licenses. The authors (Sanabria et al., 2014) [8] compare three open data creation initiatives in South America (Brazil, Colombia, Chile), but in a similar way, but on a reduced scale. Authors rather focus on open government policy, citizen engagement, and the use of new technologies.

The authors (Egger-Peitler \& Polzer, 2014) [9] and (Palmirani et al., 2014) [10] also evaluate the status of the initiative on open government data; however, they have more specific goals. The first attempt to analyze the relationship between European countries and European authorities (mainly in Venice), both from consumers and from producers. To understand the relationship between Italian law and the recently adopted Law on Transparency. The authors (Martin, Foulonneau \& Turki, 2013) [11] also have a specific purpose; to evaluate the level of open data as metadata.

In the research of Astin A.W., [12] he assesses four traditional ways of determining and assessing the quality of education.

Despite this, it can be seen that there is a lot of research in the field of transparency of state bodies and quality education, but the study of the relationship between these concepts has not been studied much. Therefore, this article will be relevant, especially since the role of the quality of education in the transparency mechanism of state bodies today is becoming increasingly important on the world stage.

\section{Data and methodology}

For empirical studies were used various statistics, materials and articles related to public administration and quality education. Survey, statistical and analytical methods were used in this study project. Scientific literature studies, existing situation evaluation and assessment were applied in current research.

In addition, the ideas of al-Farabi from different sources were gathered for improved transparency of the state authorities in the context of global economic and social developments.

\section{Results and Discussion}

Indeed, when we talk about effective public administration, we mean a wide range of issues and processes, the main of which are transparency, openness, accountability, and taking into account the opinions of citizens in the process of making government decisions. The figure below shows some issues and processes.

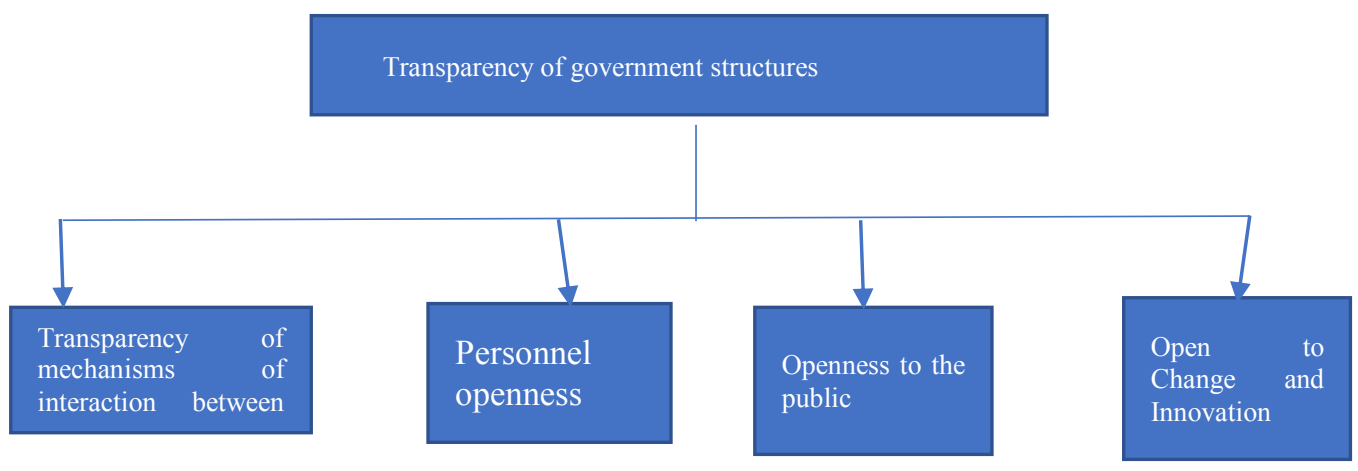


Fig. 1. Transparency of government structures [13]

You cannot talk about transparency and accountability without observing the rules for admission to the civil service, the ethics of the civil service, well-defined internal procedures and the reduction of corruption risks, both in the work of state bodies themselves and in the provision of public services.

At the beginning of this year, the head of state announced a new strategic reform in the economic sphere - "Third Modernization: Global Competitiveness", where the main pillars of the reforms are the implementation of OECD best practices and recommendations in the fields of education, the economy, public administration and socio-cultural development.

Not just the term "transparency" has completely settled, but the institute of transparency is making strides in the modern world. One can plainly observe the propensity to unite the principle of transparency of political force as one of the legitimate standards. A enormous gigantic group of economically developed states is actively adopting applicable laws and regulations, the state structure of which is normally positioned among democracies working actively in this direction. These countries include, above all else, the Scandinavian countries, the countries of Central Europe, Australia, Canada, New Zealand, Japan. [14]

It is clear that the transparency of relations between the government and the population is designed to advance the process of formation of civil society in Kazakhstan, to affirm in the minds of people the triumph of the principles of democracy, and along with this, the fundamental provisions of the Constitution of the Republic of Kazakhstan on democracy. [15] The openness of power is both a paramount task and an effective means of ongoing administrative reform in recent years aimed at creating an effective state.

Real mechanisms for improving the public administration system and increasing the transparency of public service in particular, are proposed in the President's Message "New Development Opportunities in the Fourth Industrial Revolution." Therefore, digitalization offices are created in each state body, which will analyze, evaluate and monitor all projects of the state program "Digital Kazakhstan", adopted on December 12, 2017. Ensuring the widespread provision of public services in electronic form will facilitate and accelerate communication between citizens and executive bodies; to eliminate restrictions imposed, for example, by the work schedule or the geographical remoteness of executive authorities; ensure accessibility to information, its authenticity and confidentiality. Information technology has a great impact on improving the efficiency of public authorities and on improving their relations with citizens. They are necessary to take into account the comments and suggestions of citizens in real time and prompt response. Integration of information systems of government agencies will allow us to switch to the provision of individual public services to complex ones on the basis of the one-window principle. Digitalization of the processes of obtaining state support by business will be provided.

Thus, for modern Kazakhstan, the professionalization of the public service system, based on the principles of transparency, is the most important factor in ensuring the competitiveness of the public administration system and the quality of public services to the population. The use of transparency mechanisms of the political process in public administration will make public policy in Kazakhstan more accessible to understanding by the majority of the population. This applies in particular to areas such as social policy, health, education, security.

To date, Kazakhstan has adopted the Law on Access to Information, it enshrines the obligation to provide information, facilitating access to information, disclosing information, and obligatorily publishing it. 
The "Open Government" provides for the publication and discussion of budget programs and reports on their implementation, draft laws and regulations, the possibility of using open data from government agencies, establishing feedback through an open dialogue, and evaluating the effectiveness of government agencies. In 2015, the Law on Public Councils was adopted, which expands the ability of citizens to participate in government decisions, along with the laws on the procedure for considering appeals of individuals and legal entities and the law on access to information.

Reforms are being carried out in the field of public service, to ensure the independence of judges.

There is a process of automation of public services. Today, $47 \%$ of public services can be received in electronic form, and 24\% through the Government for Citizens Corporation. The plans are to bring the provision of public services in electronic form to $90 \%$.

The development and adoption of the law "On Access to Information" was provided for by various strategic and program documents "Five Institutional Reforms", the Plan of the Nation "100 Concrete Steps", the Anti-Corruption Strategy of the Republic of Kazakhstan for 2015-2025. It means an important step in putting into practice the right to access information, ensuring transparency and accountability of public authority. This law is a tool to prevent and detect corruption.

However, according to the Global Rating of Information Laws, our law was rated 61 out of 150 points. Kazakhstan takes 99th place in the overall ranking of 111 countries where similar laws have been adopted. In addition to compliance with standards, experts evaluate how the law is implemented in practice. Therefore, even if the law does not meet all standards, but is widely applied in practice, it receives a higher rating.

At the same time, under the influence of technological progress and the development of advanced communication technologies, the world is inevitably and persistently entering a new information era. At the same time, society is facing serious global challenges. Economic, technical and scientific progress is far ahead of the development of spiritual and moral values of industrial civilization, contributing to the preservation of old and the creation of new forms of moral degradation, violence and conflict. Achievements of science and technology are introduced both for the good of man and to the detriment of him. The main problem of the current millennium is the spiritual revival of society, the search for the meaning and purpose of life in accordance with the modern era. [16]

Higher education is the most important component in shaping the goals of this process. Universities over the centuries, along with the transfer of knowledge to their students, raised them in high spirituality and formed real citizens of their time. Today, in an era of rapid change in the paradigm of development of society, academic circles continue to fulfill this noble social mission. The response to new global challenges was the program "EDUCATION of Global Citizenship", initiated by the United Nations, which provides for the education and upbringing of a young man as a member of global society and a citizen of the world.

Achieving this strategic goal cannot be successful without the formation of a stable spiritual and moral platform in the development of universities. The mission of modern universities is becoming increasingly apparent: achieving global education goals through the exchange of civilizational humanistic values with future citizens of society.

With the growing interdependence of countries around the world, the creation of a single labor market, goods, capital, including the knowledge market, "education cannot be built solely on a national foundation." Universities today must be prepared for change, open, and receptive to better achievements. [17] In this regard, one of the achievements of the EU is the successful implementation of programs that enable students to study in different countries, learn their language and culture. According to E. Giddens, modern universities form a kind of "cosmopolitan" generation, which will play a decisive role in the future development of Europe. 
The mission of modern universities is based on a deep understanding that we are connected with each other as citizens of a global multicultural community. The time has come when higher education should fully assume its fundamental role in shaping a culture of peace, creating more just, peaceful and tolerant societies. The educational and social environment of the university from the very beginning has a special strategic cross-cultural potential that can fulfill the tasks of educating young people in the spirit of global citizenship. Given the fragile balance of world civilization and the escalation of conflicts, learning as a quantitative accumulation of knowledge without spiritual content makes no sense.

The global goal of modern universities is to educate citizens around the world. Within the framework of the project "Formation of Citizens of a Virtuous Society", it is proposed to contextualize at the national and civilizational levels the models of moral education of youth based on the integration of knowledge and spirituality.
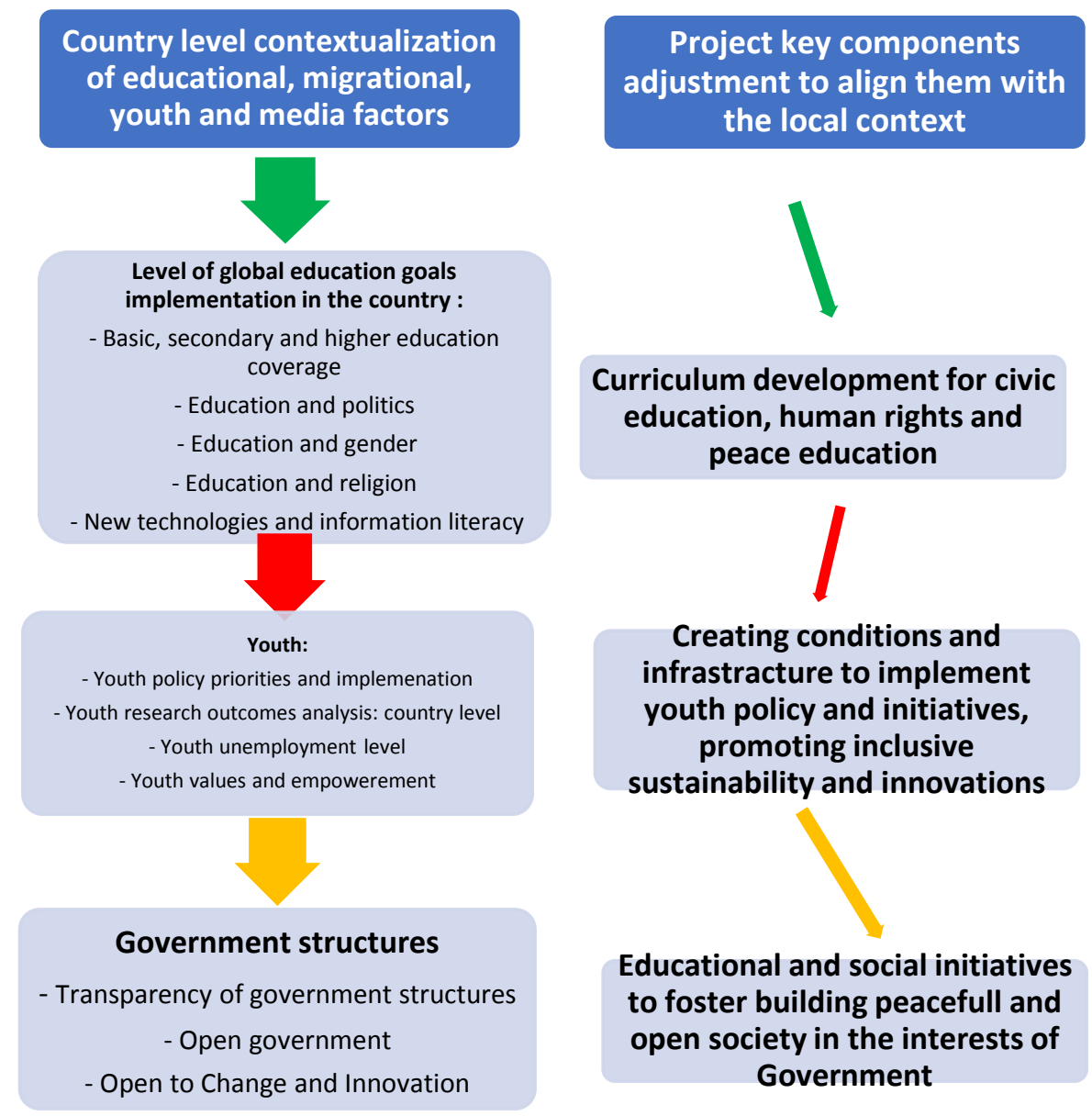

Creating conditions and infrastracture to implement youth policy and initiatives, promoting inclusive sustainability and innovations

\section{Educational and social initiatives to foster building peacefull and open society in the interests of Government}

Fig. 2. Contextualization model of interconnection between cultures and building bridges between communities 
In this regard, the ideas of the great oriental thinker al-Farabi on the relationship between knowledge and morality, education and upbringing are especially in demand today. As alFarabi emphasized, "knowledge and good morality" science and morality should go hand in hand. Very relevant is his doctrine of the Virtuous Man and the Virtuous Society, where special significance is attached to virtues as sources of human happiness. The main goal of education is to teach a person to overcome his negative character traits and contribute to the development of positive qualities.

We can replace any forms of social destructiveness that arise in the modern world with virtues: justice, responsibility, humanity, tolerance, and other high moral qualities. Their implementation in our daily lives transforms morality from speculative construction into an effective component of social progress and the sustainable development of civilization.

In addition to educational and scientific activities, the University's mission should be aimed at promoting the socio-economic development of the country. A modern university should be a source of social advancement and the growth of social welfare. Carrying out activities not only at the national, but also at the global level is a new facet of the mission that a modern university must fulfill. These are the involvement of universities in environmental issues, conflict prevention and sustainable development.

The university plays an important role in the formation of new leaders who will be able to change the world for the better. It is necessary to develop cooperation between the university and the state and civil society in order to make constructive decisions on certain issues.

Kazakhstan seeks to achieve its long-term goals in the field of economic and social transformations, and in particular, to become one of the 30 most developed countries by 2050; nevertheless, serious problems still exist in the public administration system. The management structure and processes that are influenced by the history of their occurrence cause these problems.

Much remains to be done to address the deficiencies associated with low levels of transparency and accountability in the public sector and the need to strengthen professional ethics and fight corruption at all levels of government.

The First President of the Republic of Kazakhstan - Elbasy state N.A. Nazarbayev in his article "Looking to the Future: Modernization of Public Consciousness" notes that "the peculiarity of tomorrow is that it is the competitiveness of a person, and not the availability of mineral resources, that becomes a factor for the success of a nation". [18] Without effective human capital, joining the thirty developed countries of the world is impossible. Kazakhstan can increase the efficiency of public administration and the quality of political processes, due to the emphasis on the implementation of reforms and their support through increased transparency of legal regulation, strengthening the rule of law and wider mechanisms for public discussion.

The university plays an important role in the formation of new leaders who will be able to change the world for the better. It is necessary to develop new educational programs aimed at fostering global citizenship. It is education in the spirit of global citizenship that forms students' values, knowledge and skills, which are based on respect for human rights, social justice, cultural diversity, environmental culture, and through which young people can become responsible citizens of the world. Education is called upon to use its potential to consolidate society, to preserve peace, to overcome ethno-national tensions and social conflicts on the basis of the priority of individual rights, the equal rights of national cultures and various faiths. It is necessary to develop cooperation between the university and the state and civil society in order to make constructive decisions on certain issues. Education is a cementing element in the information field of modern culture. Moreover, those countries that are catching the wind of change are beginning to actively switch to new paradigms of educational technology, moving away from old models, cliches and misconceptions. The 
problem of the quality of education is inextricably linked with the problem of human quality, with its development, which forms public intelligence as a factor in the progressive development of society.

\section{CONCLUSION}

Thus, in modern conditions, access to information, along with motivation and the ability of citizens to rationally use all types of resources, plays an important role in strengthening the country's competitiveness. Education, like culture, largely determines the welfare of the state, the specifics of national consciousness. The general mission of education is the dissemination and preservation of accumulated knowledge to ensure the growth of human capital and civilizational development. Educational activity is the transfer and dissemination of the volume of intellectual achievements in order to form a person as a person and a member of a community, an executor of socially important functions. The study of the educational environment and population level should always be in the center of attention of scientists.

It should be remembered that now there is an urgent need not only for individual components in the formation of an individual's education, but about the relationship of the whole complex: knowledge and morality, education and upbringing.

Only in this case this whole complex will guarantee the acquisition by the economically active population of high professional skills, the formation of new leaders in a new format, ready to improve effective public administration. It will include a wide range of issues and processes, the main of which are transparency, openness, accountability, taking into account the opinions of citizens in the process of making state decisions.

The present puts forward new requirements for the educational process, it allows you adapt quickly to the latest achievements of scientific and technological progress, to be individualized, to correspond to the real prospects for the development of industries, to serve as a prerequisite for the formation of human capital. In developed countries, the main factors in creating an effective system of government bodies, achieving a high standard of living of citizens is social justice, solidarity and openness in the redistribution of income by government bodies.

\section{References}

1. President of Kazakhstan Kassym-Jomart Tokayev's State of the Nation Address, September 2, 2019

2. Schultz, T.W. Investing in people: Schooling in low income countries. Econ. Educ. Rev. 1989, 8, 219-223.

3. Denison, E.F. The Sources of Economic Growth in the United State \& the Alternatires Before Us; Committee for Economic Development: New York, NY, USA, 1962.

4. William, E.; Rbelo, S. Fiscal policy and economic growth: An empirical investigation. J. Moneytary Econ. 1993, 32, 417-458.

5. Collins, S.M.; Bosworth, B.P.; Rodrik, D. Economic growth in East Asia: Accumulation versus assimilation. Brookings Pap. Econ. Act. 1996, 19, 135203.

6. Sylwester, K. Income inequality, education expenditures, and growth. J. Dev. Econ. 2000, 63, 379-398. 
7. Petychakis, M., Vasileiou, O., Georgis, C., Mouzakitis, S., \& Psarras, J. (05 2014). A state-of-the-art analysis of the current public data landscape from a functional, semantic and technical perspective. Journal of theoretical and applied electronic commerce research, 9, 34-47

8. Sanabria, P., Pliscoff, C., \& Gomes, R. (2014). E-government practices in south americancountries: Echoing a global trend or really improving governance? The experiencesof Colombia, Chile, and Brazil. In M. Gascó-Hernández (Ed.), Open Government, Public Administration and Information Technology. 4. (pp. 1736).

9. Egger-Peitler, I., \& Polzer, T. (2014). Open data: European ambitions and local efforts.

Experiences from austria. In M. Gascó-Hernández (Ed.), Open Government, Public Administration and Information Technology, vol. 4. (pp. 137-154).

10. Palmirani, M., Martoni, M., \& Girardi, D. (2014). Open government data beyond transparency. In A. Ko, \& E. Francesconi (Eds.), Electronic Government and the Information Systems Perspective, Lecture Notes in Computer Science. 8650. (pp. 275-291).

11. Martin, S., Foulonneau, M., Turki, S., \& Ihadjadene, M. (2013). Open data: Barriers, risks, and opportunities. European Conference on eGovernment, Como, Italy [June 13-14].

12. Astin, A .W . Achieving Educational Excellence: A Critical Assessment of Priorities and Practices in Higher Education . San Francisco: Jossey-Bass, 1985 $.254 \mathrm{p}$.

13. Mikhaylova N. 2011. Opening state structures in the framework of improvement of the state and municipal management system. (pp.13-19).

14. Buluktaev Y, Website Kazakhstan Institute for Strategic Studies under the President of the Republic of Kazakhstan http://kisi.kz/index.php/ru/56stati/buluktaev-yurij-ochirovich/33-sankhaeva-zhanar-starshij-nauchnyjsotrudnik-otdela-sotsialno-politicheskikh-issledovanij-kazakhstanskogoinstituta-strategicheskikh-issledovanij-pri-prezidente-rk-kaziss-v-poslanii2018-goda-prezident-rk-n-a-nazarbaev-oboznachil-10-klyuchevykhnapravlenij-obshchestvenno-politicheskogo-i-ekonomicheskogo-razvitiyastrany-pri-etom-bolshoe-vnimanie-udeleno-tesnoj-vzaimosvyazi-rynka-truda-iobrazovani.

15. Kenzhegaranova, M., Kunanbayeva, D., Azimbekova, A., Podmetina, D., Kazbekova, Z. 2016. Role of government on entrepreneurship development in Kazakhstan. International Journal of Economic Perspectives 10(3), c. 35-46

16. Turginbayeva, A., Smagulova, G., Ashirbekova, L., Malikova, R. Topical issues of management in modern education and ways to solve them. 2018, P. 36433647

17. Mutanov G. 2018. Role of universities in global citizenship addressed during seminar at UN Headquarters https://academicimpact.un.org/content/roleuniversities-global-citizenship-addressed-during-seminar-un-headquarters

18. Nazarbayev N. - The First President of the Republic of Kazakhstan - Elbasy state article "Course Towards the Future: Modernization of Kazakhstan's Identity" 2017. 